\title{
PRINSIP SYARIAH DALAM PEMBAHARUAN KONSEP PERKOPERASIAN DI INDONESIA
}

\author{
Burhanuddin Susamto \\ Fakultas Syariah Universitas Islam Negeri Maulana Malik Ibrahim \\ Email: burhanuddin@syariah.uin-malang.ac.id
}

\section{Abstracts}

Cooperative has been a part of the existing business entity in the community. This theme is important to be reviewed in Sharia principles approach for the development of cooperative concept in Indonesia. Through cooperative, the members are able to make contracts/ transactions both among members and other parties. To build the relationship, all parties need syar'i contracts which functions as the underlying contract. Therefore, to have strong validity, the implementation of necessary sharia principles is not only at the conceptual level but also at the operational level from the cooperative establishment to its dissolution. By implementing the sharia principles in developing the concept of cooperative legal entity, it is expected to give opportunity for cooperative practitioners to practice their divine values.

Koperasi telah menjadi bagian dari badan usaha di tengah masyarakat. Tema ini penting dikaji kembali demi pengembangan konsep perkoperasian di Indonesia dengan pendekatan prinsi-prinsip syariah. Badan usaha koperasi memungkinkan para anggota untuk melakukan perikatan/transaksi baik dengan sesama anggota maupun dengan pibak lain. Untuk membangun hubungan tersebut semua pihak pasti membutubkan akad-akad syar'i yang fungsiny sebagai dasarperikatan (underlying contract). Karenanya, agar memiliki keabsaban yang kuat, implementasi prinsip-prinsip syariah adalah keniscayaan tidak hanya pada level konseptual melainkan juga pada level operasional, mulai dari pendirian koperasi hingga pembubarannya. Dengan mengimplentasikan prinsip-prinsip syariab dalam pembaharuan konsep badan bukum koperasi, diharapkan lebih membuka peluang bagi para praktisi perkoperasian untuk. mengamalkan nilai-nilai ilahiya.

Keywords: cooperative, sharia principles, business entity 


\section{Pendahuluan}

Koperasi didirikan bertujuan memajukan kesejahteraan anggota pada khususnya dan masyarakat pada umumnya serta ikut membangun tatanan perekonomian nasional dalam rangka mewujudkan masyarakat yang maju, adil, dan makmur berlandaskan Pancasila dan Undang-Undang Dasar 1945. Koperasi mendukung terwujudnya kesejahteraan bagi anggota melalui pemberian manfaat secara langsung kepada anggota dan pemberian hak Sisa Hasil Usaha (SHU). Koperasi mendukung kesejahteraan bagi masyarakat umum melalui jasa yang ditawarkan serta fungsi pemberdayaan yang dilakukan koperasi.

Karakter utama yang dianut koperasi dalam menjalankan usaha adalah sistem identitas ganda (the dual identity of member) yang melekat di dalamnya, yaitu selain anggota sebagai pemilik usaha (owners) dan sekaligus pengguna jasa koperasi (user own oriented firm). Diantara identitas keanggotaan ditandai dengan adanya penyertaan modal anggota baik dalam bentuk simpanan pokok/ wajib maupun simpanan sukarela. Sedangkan identitas sebagai pengguna jasa ditandai dengan keaktifan anggota dalam bertransaksi untuk memenuhi kebutuhan yang disediakan oleh koperasi.

Secara umum, paling tidak ada tiga kategori pendapat terkait dengan praktik koperasi. Berlakunya koperasi dari dulu hingga sekarang ini menunjukan kalau masyarakat banyak yang berpandangan bahwa koperasi dari aspek hukumnya tidak ada persoalan karena dianggap mendatangkan kemaslahatan. Ada kecendrungan bahwa kebolehan praktik koperasi (misalnya simpan pinjam) menurut pendapat ini adalah seiring dengan kebolehan praktik bunga pada bank konvensional. Namun pandangan ini sudah sedikit bergeser setelah mulai tumbuhnya lembaga-lembaga keuangan syariah. ${ }^{1}$

Kelompok yang menolak sama sekali berpandangan bahwa menetapkan hukum tentang koperasi bukan hanya dilihat dari segi produknya, seperti simpan pinjam, tetapi secara keseluruhan mulai dari aspek perikatan dasarnya. Artinya, dari perikatan dasar mereka sudah berkesimpulan bahwa koperasi tidak syar'i karena dianggap menyalahi ketentuan akad syirkah dalam Islam. ${ }^{2}$ Sedangkan pendapat yang ketiga cendrung menerima badan usaha koperasi dengan syarat harus diperbaiki konsepnya. ${ }^{3}$ Menurut penulis, konsep koperasi yang syar'i tidak hanya dilihat dari kehalalan lingkup usahanya melainkan juga harus dilihat dari konsep pendiriannya. Implementasi prinsip-prinsip syariah hanya pada lingkup usahanya menyebabkan konsep keilmuan koperasi syariah menjadi tidak komprehensif.

1 Burhanuddin S., Koperasi Syariah dan Pengaturannya di Indonesia, (Malang: UIN Maliki Press, 2013), h.. 5-6.

2 Taqiyuddin An-Nabhani, An-Niz̧ham al-Iqtishadi fí al-Islam, (Beirut: Darul Ummah, 1990), h. 178-181.

3 Burhanuddin S., Koperasi Syariah dan Pengaturannya di Indonesia, h. 6. 
Karenanya mengkaji implementasi prinsip-prinsip syariah dalam pembaharuan konsep perkoperasian di Indonesia merupakan suatu hal penting.

\section{Metode Penelitian}

Jenis penelitian ini adalah penelitian hukum normatif (normatie legal research $)^{4}$ yaitu penelitian yang menjadikan teks hukum sebagai objek kajiannya. Hukum disini maksudnya adalah akad-akad yang dapat diterapkan dalam pendirian koperasi serta regulasi yang mengatur pendirian tersebut. Suatu perikatan tidak boleh dijalankan sekehendak mereka melainkan harus mendasarkan akad-akad tertentu sebagai dasar perikatannya (underlying contracts). Pendekatan ${ }^{5}$ yang digunakan dalam penelitian ini adalah pendekatan konseptual (conceptual approach) dan pendekatan perudang-undangan (statue approach). Pendekatan konseptual digunakan untuk mengungkap konstruksi penggunaan akad dalam pendirian koperasi. Sedangan pendekatan perUndang-Undangan digunakan untuk memetakan berlakunya regulasi terkait koperasi syariah. Sumber data yang telah terkumpul kemudian akan dianalisis melalui metode istiqra' yaitu pembacaan secara mendalam terhadap suatu objek tertentu sebelum ditetapkan kesimpulan yang bersifat umum.

\section{Pembahasan}

Tidak semua usaha ekonomi untuk mendapatkan rizki bisa dijalankan secara perseorangan, melainkan harus melalui kerjasama. Kerjasama ekonomi dapat dijalankan melalui berbagai wadah diantaranya adalah badan usaha koperasi. Kenyataan bahwa sebagai badan usaha modern konsep perkoperasian belum dikenal dalam tradisi fiqh. Tema ini penting untuk dikaji kembali demi pebaharuan konsep perkoperasian di Indonesia dengan pendekatan prinsi-prinsip syariah. Melalui badan usaha koperasi memungkinkan para anggota untuk melakukan perikatan/ transaksi baik diantara sesama anggota maupun dengan pihak lain sebagai pengguna jasa koperasi. Untuk membangun hubungan tersebut semua pihak pasti membutuhkan akad-akad syar'i yang fungsinya sebagai dasar perikatan

4 Penelitian hukum normative disebut juga pebelitian hukum doctrinal. Penelitian jenis ini acapkali hukum dikonsepsikan sebagai apa yang tertulis dalam peraturan perUndang-Undangan (law in books) atau hukum dikonsepsikan sebagai kaidah/ norma yang merupakan patokan berprilaku manusia yang dianggap pantas. Lihat, Amiruddin dan Zainal Asikin, Pengantar Metode Penelitian Hukum, (Jakarta: Rajawali Pers, 2003), h. 118.

5 Dalam metode penelitian hukum, ada beberapa pendekatan yang dapat digunakan seperti pendekatan Undang-Undang (statute approach), pendekatan kasus (case approach), pendekatan historis (bistorical approach), pendekatan komparatif (comparative approach), dan pendekatan konseptual (conceptual approach). Lihat Peter Mahmud Marzuki, Penelitian Hukum, (Jakarta: Penerbit Kencana, 2014), h. 133. 
(underlying contract). Karenanya agar memiliki keabsahan yang kuat, implementasi prinsip-prinsip syariah yang merupakan suatu keniscayaan bukan hanya pada level konseptual melainkan juga pada level operasional mulai dari pendirian koperasi hingga pembubarannya.

Pendirian koperasi selalu diawali dengan adanya rapat persiapan dari para anggotanya. Pelaksaan rapat anggota wajib dituangkan ke dalam bentuk: (1) Berita acara rapat pendirian koperasi, yaitu risalah rapat yang disusun secara rapi untuk ditandatangani oleh notaris pembuat akta koperasi yang dimaksudkan sebagai alat bukti otentik; (2) Notulen rapat pendirian, yaitu laporan mengenai jalannya rapat yang disusun secara rapi untuk ditandatangani oleh pimpinan dan sekretaris rapat sebagai dokumen resmi. Notulensi dan berita acara rapat merupakan kelengkapan administrasi yang harus dipenuhi untuk memperlancar proses pendirian badan hukum koperasi. Prinsip syariah yang dapat diterapkan terkait rapat anggota adalah prinsip musyawarah (syüra). Adapun landasan syariat prinsip musyawarah mendirikan koperasi adalah firman Allah yang artinya: Sedang urusan mereka (diputuskan) dengan musyawarah antara mereka (QS. Al-Syura[42]: 38);

Maka dengan rahmat dari Allah engkau bersikap lemah lembut terhadap mereka. Sekiranya engkau bersikap kasar dan berhati keras, niscaya mereka akan menjaubkan diri dari sekelilingmu. Karena itu maafkanlah mereka, mohonkan ampun bagi mereka, dan bermusyawarahlah dengan mereka dalam urusan. Kemudian apabila engkau telab membulatkan tekad, bertawakkallab kepada-Nya (QS. Ali-Imran [3]: 159).

Dalam ayat tersebut Allah telah memerintahkan kepada Nabi untuk berpegang pada prinsip musyawarah (syura). Kalau Nabi sebagai orang yang ma'sum, diperintahkan untuk bermusyawarah dalam masalah urusan umat, maka umatnya sebagai manusia yang tidak maksum lebih-lebih lagi harus melakukan musyawarah untuk mewujudkan kemaslahatan. Rasulullah SAW adalah orang yang paling senang bermusyawarah dengan para sahabatnya. Dalam suatu riwayat Abu Hurairah r.a mengatakan:

Saya tidak pernah melihat seseorang yang lebih banyak bermusyawarah dengan sababatsahabatnya daripada Rasulullah (HR. Tirmidzi dan Ibnu Majah). ${ }^{6}$

Dalam musyawarah dibutuhkan peserta dari kalangan anggota koperasi untuk mencapai kesepakatan bersama. Dengan mengikutsertakan para anggota koperasi sebagai peserta musyawarah, selain akan mengakomodasi berbagai pendapat demi kesempurnaan suatu putusan, diharapkan juga tercipta suatu

6 Al-Syafi'ie, Musnad al-Syafi'ie (Bairut: Dar al-Kutub al-'Ilmiyyah, t.t.), jilid. 1, hlm. 277, No. 1328. Lihat juga: Ibn Hibban, Shabih ibn Hibban (Bairut: Muassasah al-Risalah, 1993), hlm. 11, No. 4872. Lihat http://makalah85.blogspot.co.id/2011/05/musyawarah-dalam-perspektif-al-quran.html. 
kesepakatan/ kesepahaman dari para peserta sehingga melahirkan sikap keridhaan (tarâdhin). Keridhaan dibangun bukan hanya dari adanya kesamaan pendapat, melainkan juga dari adanya perbedaan pendapat yang didasari oleh prinsip saling menghargai (tasamub). Adanya keridhaan dari para anggota koperasi akan melahirkan sikap tanggung jawab untuk turut menjalankan hasil suatu kesepakatan. Tujuan dari musyawarah adalah untuk saling menasehati dalam mengambil keputusan terbaik yang diridhai oleh Allah.

Tema penting yang harus dibahas dalam rapat anggota pendirian koperasi adalah penyusunan anggaran dasar (AD) dan anggaran rumah tangga (ART). Anggaran dasar adalah seperangkat ketentuan yang dibuat berdasarkan kesepakatan untuk mengatur hubungan hukum dalam organisasi koperasi yang akan dijalankannya. Peraturan yang terdapat dalam anggaran dasar koperasi bersifat mengikat bagi para anggotanya. Sama halnya dengan badan usaha lainnya, format yang dibuat dalam anggaran dasar harus mengikuti standar yang berlaku pada umumnya, meskipun secara materi keberadaanya dapat disesuaikan dengan bidang usaha yang dijalankan. Karena itu, sepanjang anggaran dasar yang dibuat atas kesepakatan itu tidak bertentangan dengan Undang-Undang yang berlaku, maka format anggatan dasar koperasi pun juga dapat dikondifikasi sesuai dengan kebutuhan anggotannya. Sedangkan ketentuan pendukung yang tidak termuat dalam anggaran dasar dapat dihimpun tersendiri melalui aturan rumah tangga (ART).

Rapat pembentukan koperasi wajib dihadiri oleh anggota pendiri koperasi. Untuk pembentukan koperasi primer, rapatnya dihadiri oleh sekurang-kurangnya 20 orang pendiri, sedangkan koperasi sekunder sekurang-kurangnya 3 (tiga) koperasi yang diwakili orang yang telah berdasarkan keputusan rapat anggota koperasi yang bersangkutan. Rapat pembentukan koperasi dipimpin oleh seorang atau beberapa orang dari pendiri atau kuasa pendiri. Rapat pembentukan dihadiri oleh pejabat yang berwenang dengan ketentuan sebagai berikut: (1) Pembentukan koperasi sekunder dan primer tingkat nasional dihadiri oleh pejabat Kementerian Koperasi dan Usaha Kecil dan Menengah;(2) Pembentukan koperasi sekunder dan primer tingkat propinsi dihadiri oleh pejabat dinas/ instansi yang membidangi koperasi tingkat propinsi; (3) Pembentukan koperasi sekunder dan primer tingkat kabupaten/ kota dihadiri oleh pejabat dinas/ instansi yang membidangi koperasi tingkat kabupaten/kota.?

7 Pasal 5 Peraturan Menteri Negara Koperasi dan Usaha Kecil dan Menengah No: 1/Per/M.KUKM/ I/2006 tentang Petunjuk Pelaksanaan Pembentukan, Pengesahan Akta pendirian dan Perubahan Anggaran Dasar Koperasi. 
Untuk mendirikan koperasi, masing-masing anggota harus melakukan perikatan antara satu dengan yang lainnya. Akad yang paling dasar digunakan untuk perikatan dalam mendirikan koperasi adalah akad syirkah. Dalam suatu syirkah, seorang dapat mewakili anggota lainnya untuk melakukan akad dengan pihak ketiga. Apabila akibat akad dengan pihak ketiga mendatangkan keuntungan, maka keuntungan itu menjadi milik bersama yang akan dibagi sesuai kesepakatan. Begitupula sebaliknya, apabila akibat akad dengan pihak ketiga mengalami kerugian, maka masing-masing anggota bertanggungjawab atas risiko secara bersama-sama kecuali kerugian tersebut terbukti disebabkan karena faktor kesengajaan/ pelanggaran. Ketentuan ini mengacu pada kaidah yang menyatakan: "Keuntungan dibagi berdasarkan syarat kesepakatan, sedangkan resiko

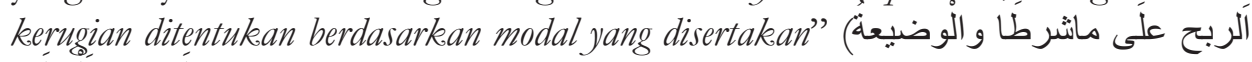
(على قدرِ المالين (Adapun bentuk tanggung jawab anggota dalam syirkah menurut ketentuan KHES sebagai berikut: (1) Setiap anggota syirkah mewakili anggota lainnya untuk melakukan akad dengan pihak ketiga dan/ atau menerima pekerjaan dari pihak ketiga untuk kepentingan syirkab; (2) Masing-masing anggota syirkah bertanggung jawab atas risiko yang diakibatkan oleh akad yang dilakukannya dengan pihak ketiga dan/ atau menerima pekerjaan dari pihak ketiga untuk kepentingan syirkah; (3) Seluruh anggota syirkah bertanggung jawab atas risiko yang diakibatkan oleh akad dengan pihak ketiga yang dilakukan oleh salah satu anggotanya yang dilakukan atas persetujuan anggota syirkab lainnya. ${ }^{8}$

Dalam kerjasama modal (amwâl), setiap anggota syirkah harus menyertakan modal berupa uang tunai atau barang berharga. Apabila kekayaan anggota yang akan dijadikan modal syirkah bukan berbentuk uang tunai, maka kekayaan tersebut harus dijual dan/ atau dinilai terlebih dahulu sebelum melakukan akad kerjasama. Syirkah yang masuk kategori persekutuan/ kerjasama modal adalah'inân dan mufawadhah, sedangkan syirkah yang tidak termasuk kategori kerjasama modal adalah abdân dan wujûh.

Untuk mendirikan usaha berbadan hukum koperasi, diperlukan adanya ketersediaan modal. Modal utama mendirikan koperasi adalah diwujudkan dalam bentuk penyertaan dana yang berasal dari para anggotanya. Modal yang telah diserahkan oleh para anggota menjadi milik bersama dalam wadah koperasi. Masing-masing anggota menggunakan/ mentransaksikan dana sebagai wakil koperasi, karena itu segala keuntungan dari penggunaan dana menjadi milik koperasi. Adapun sumber modal yang selama ini menjadi tumpuan dalam setiap mendirikan koperasi adalah sebagai berikut:

8 Pasal 141 Peraturan Mahkamah Agung No. 2 Tahun 2008 tentang Kompilasi Hukum Ekonomi Syariah 
Modal koperasi dari anggota sendiri merupakan modal yang mengandung resiko (equity). Termasuk kategori modal sendiri dalam mendirikan koperasi misalnya:

Simpanan pokok/ wajib adalah penyertaan modal dengan jumlah sama yang diwajibkan bagi semua anggota ketika masuk menjadi anggota koperasi. Penyertaan melalui simpanan pokok dapat dipersyaratkan misalnya: (1) Wajib dibayarkan pada saat akan menjadi anggota; (2) Jumlah nominalnya semua sama bagi anggota; (3) Penyertaan tidak dapat diambil kembali kecuali yang bersangkutan berhenti sebagai anggota. Meskipun surat bukti penyetoran modal dapat berupa keterangan yang dibuat sendiri oleh para pendiri koperasi, namun penjelasan keterangan tersebut harus tetap menggambarkan jumlah sebenarnya modal yang telah disetor. Apabila modal itu disetorkan untuk simpanan wajib dengan jumlah yang sama (Rp. X + Rp. X), maka akad yang digunakan adalah syirkah mufawadhah.

Simpanan sukarela adalah penyertaan modal dengan jumlah berbeda yang bersifat sukarela bagi semua anggota. Penyertaan melalui simpanan wajib dapat dipersyaratkan misalnya: (1) Dapat dibayarkan setiap saat secara sukarela; (2)Jumlah nominalnya tidak harus sama untuk masing-masing anggota; (3) Penyertaan hanya dapat diambilsebagian/seluruh pada periode tertentu sesuai kesepakatan. Apabila jumlah modal yang disetorkan melalui simpnn sukarela nominalnya berbeda (Rp. $\mathrm{X}+\mathrm{Rp} . \mathrm{Y})$, maka akad yang digunakan adalah syirkab inan.

Dana cadangan adalah penyertaan modal bersama yang diperoleh dari penyisihan sisa hasil usaha untuk menambah modal mandiri koperasi. Dana cadangan diperoleh dari penyisihan sebagian sisa hasil usaha (SHU) sebelum dibagikan tiap tahun. Tujuan dari alokasi dana cadangan adalah: (1) Untuk menambah jumlah perodalan yang dapat mendukungpengembangan usaha koperasi; (2) Mengantisipasi kemungkinan terjadinya risiko. Keuntungan dari hasil usaha koperasi merupakan hak semua anggota. Karena itu apabila ada yang disisihkan sebagai dana cadangan, maka alokasi jumlah (\%) harus atas persetujuan semua anggota baik melalui ketentuan $\mathrm{AD} / \mathrm{ART}$ maupun melalui rapat anggota.

Untuk pengembangan modal usaha, koperasi memungkinkan untuk mengajukan pembiayaan baik yang berbasis profit (tijarab) maupun non profit (tabarru'). Akad yang dapat digunakan untuk mendapatkan pembiayaan berbasis tijarah adalah: (a) Pembiayaan untuk mendapatkan modal tunai berbasis bagi hasil menggunakan akad mudharabah dan musyarakah amwal; (b) Pembiayaan untuk pengadaan barang modal koperasi melalui jual beli menggunakan akad murabahah dan istishna; (c) Pembiayaan melalui sewa barang modal menggunakan akad ijarah dan ijarah muntahiya bi tamlik/ IMBT. Sedangkan pembiayaan modal berbasis 
tabarru' melalui pinjaman uang tunai menggunakan akad qardh. Adapun pihak yang dapat memberikan pembiayaan pada koperasi adalah:

(a) Pembiayaan dapat diperoleh dari anggota sendiri; (b) Pembiayaan dari koperasi lainnya didasari dengan perjanjian kerja sama antar koperasi; (c) Pembiayaan dari bank dan lembaga keuangan lainnya dilakukan berdasarkan ketentuan peraturan perUndang-Undangan yang berlaku; (d) Pembiayaan melalui penerbitan obligasi syariah dilakukan sesusai ketentuan yang berlaku. ${ }^{9}$

Koperasi sebagai gerakan ekonomi rakyat perlu mengembangkan diri melalui perluasan kegiatan usahanya guna meningkatkan peranannya secara aktif dalam kegiatan perekonomian. Sehubungan dengan hal tersebut, koperasi perlu memperkuat struktur permodalannya melalui penambahan modal dengan mengikut sertakan pihak lain melalui berbagai macam pendekatan. Modal penyertaan adalah sejumlah uang atau barang modal yang dapat dinilai dengan uang yang ditanamkan oleh pemodal untuk menambah dan memperkuat struktur permodalan koperasi dalam meningkatkan kegiatan usahanya. ${ }^{10}$ Pemupukan modal dari penyertaan dapat bersumber baik dari pemerintah maupun dari masyarakat yang dilaksanakan dalam rangka memperkuat kegiatan usaha koperasi terutama yang berbentuk investasi. Karena berbentuk investasi, maka modal penyertaan bersifat ikut menanggung resiko apabila terjadi kerugian. Berbeda dengan perseroan terbatas, pemilik modal penyertaan tidak mempunyai hak suara dalam rapat anggota untuk menentukan kebijaksanaan koperasi secara keseluruhan. Namun demikian, pemilik modal penyertaan dapat diikutsertakan dalam proses pengelolaan serta pengawasan usaha investasi sesuai dengan perjanjian. Penyertaan modal para investor dalam koperasi tidak perlu dikhawatirkan menjadi korporatisasi koperasi karena keberadaan para investor tidak mungkin menggantikan kedudukan para anggota sebagai pemilik koperasi. Dalam hal ini, motif investor menyertakan modal di koperasi adalah untuk berbagai keutungan/ risiko (profit/ loss sharing) yaitu sebagai sesuatu yang lazim dalam transaksi bisnis.

Hibah sebagai bentuk pemberian (khusus untuk modal) tanpa disertai imbalan tertentu. Hibah merupakan pemberian yang diterima koperasi dari

9 Koperasi memungkinkan untuk menerbitkan semacam obligasi (surat utang) koperasi. Jika merujuk pada fatwa DSN-MUI, prinsip-prinsip syariah dapat diimplementasikan dalam penerbitan obligasi. Adapun landasan yuridis penerbitan obligasi koperasi adalah Peraturan Menteri Negara dan UKM Nomor 13 Tahun 2006 tentang Surat Utang Koperasi; Peraturan Menteri Negara Koperasi dan Usaha Kecil dan Menengah Nomor 13/ Per/M.KUKM/VII/ 2006 tentang Pedoman Teknis Program Sekuritisasi Aset Koperasi dan KUKM. Namun kenyataannya konsep obligasi syariah dalam koperasi belumlah mapan sebagaimana obligasi yang diterbitkan oleh korporasi dan pemerintah.

10 Pasal 1 angka (1) Peraturan Pemerintah No. 33 Tahun 1998 tentang Modal penyertaan dalam Koperasi 
pihak lain baik wujudnya berupa uang maupun barang. Hibah muncul sebagai komponen modal sendiri disebabkan karena banyaknya pengalaman koperasi yang menerima hibah, terutama dari pemerintah. Agar tercapai tujuannya, pelaksanaan pemberian hibah dapat ditentukan berdasarkan perjanjian antara pemberi dan penerima hibah, termasuk berlakunya persyaratan yang disepakati.

Hibah adalah pemberian harta kepada pihak lain ketika masih hidup untuk mengharapkan ridha dari Allah SW'T. Dengan kata lain, bibah merupakan akad pengalihan kepemilikan tanpa imbalan yang dilakukan seseorang ketika masih hidup. Hibab hukumnya sunnah untuk berbuat baik kepada sesama. ${ }^{11}$ Landasan syariah yang mendasari berlakunya bibah adalah sebagai berikut:

Rasulullah SAW bersabda: "Orangyang mengambil kembali pemberiannya seperti seseorang yang menjilat kembali apa yang dia muntabkan" (HR. Muslim).

Modal yang telah terkumpul melalui wadah koperasi, selanjutnya dapat digunakan untuk memulai usaha. Bentuk usaha koperasi sebenarnya boleh beraneka ragam, sehingga memungkinkan bagi koperasi syariah untuk berkembang seiring kebutuhan masyarakat. Namun secara umum, lingkup usaha koperasi idealnya selain ada yang bergerak di bidang jasa keuangan melalui penawaran produk pembiayaan (financing), juga harus ada yang berberak secara langsung di bidang usaha sector riil, misalnya usaha perdangangan. Tercapainya keseimbangan antara usaha sector riil dengan financial, diharapkan mampu mengoptimalkan fungsi koperasi dalam system perekonomian nasional.

Usaha koperasi dapat dijalankan sendiri oleh sebagian anggota yang diberi kewenangan melalui rapat anggota dan/ atau mengangkat orang lain sebagai karyawan. Apabila pengelola koperasi diangkat dari kalangan anggota dan/ atau non anggota dengan system upah (pemberian gaji bulanan), maka akad yang digunakan dalam perjanjian kerja adalah akad ijarah. Anggota yang diamanahi sebagai pengelola usaha selain berhak mendapatkan Sisa Hasil Usaha (SHU) dari perhitungan modal dan nilai transaksi, juga berhak mendapatkan upah bulanan. Sedangkan apabila ada pengelola usaha yang diangkat dari non anggota hanya berhak mendapatkan upah bulanan.

Koperasi yang baik adalah koperasi yang dapat memberikan manfaat langsung bagi para anggotanya. Manfaat koperasi dapat diwujudkan baik dalam bentuk non materi seperti pembinaan rohani, pelatihan manajemen, fasilitas kemudahan,

11 Keberadaan hibah tidak ubahnya seperti hadiah. Jadi hukumnya sunnah, dan keduannya termasuk perbuatan baik yang dianjurkan supaya berlomba-lomba di dalam melaksanakannya. Jabir al-Jaza'iri, Minhajul Muslim, edisi terjemahan (Malang: Universitas Islam Negeri Maulana Malik Ibrahim, 2014), hlm. 922 . 
dan lain-lain mupun manfaat materi seperti mulai dari pemberian diskon harta hingga pembagian SHU. Sebagai bentuk badan usaha, pembagian SHU dalam koperasi harus mencerminkan semangat prinsip bagi hasil sebagaimana halnya dalam akad syirkah. Adapun ketentuan pembagian SHU menurut peraturan yang berlaku adalah: (1) Dibagikan kepada anggota secara adil berimbang berdasarkan jumlah dana yang tertanamkan sebagai modal sendiri pada koperasi dan nilai transaksi; (2) Membiayai pendidikan dan latihan serta peningkatan keterampilan bagi pengurus, pengawas, pengelola dan karyawan koperasi; (3) Insentif bagi pengelola dan karyawan; (4) Keperluan lain dalam menunjang kegiatan koperasi; (5) Pembagian dan penggunaan SHU dilakukan dengan memasukkan komponen kewajiban (potongan) zakat atas Badan Usaha Koperasi dan zakat atasperorangan sebelum dibagikan kepada anggota yang bersangkutan. ${ }^{12}$

Gambar 1. Skema Prinsip Kerja Kopeasi Syariah

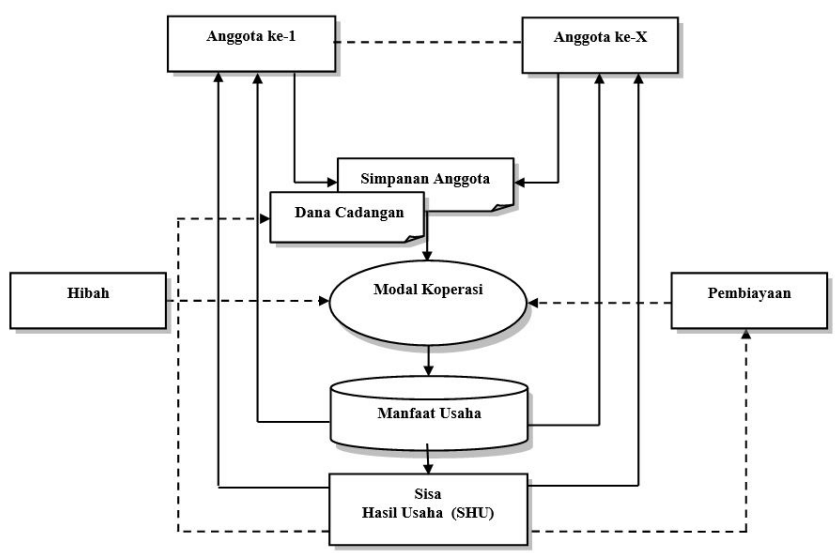

Dalam rangka menciptakan kepastian hukum dalam menjalankan kegiatan usahanya, dipandang perlu untuk memberikan status badan hukum kepada badan usaha koperasi dengan pengesahan akta pendiriannya oleh pemerintah. Status badan hukum bagi koperasi bersifat mengikat baik ke dalam maupun ke luar lembaga. Mengikat ke dalam artinya pengurus maupun anggota koperasi terikat pada ketentuan-ketentuan yang telah ditetapkan dalam AD/ART. Sedangkan mengikat ke luar artinya, semua perbuatan hukum yang dilakukan oleh pengurus atas nama dan untuk kepentingan koperasi menjadi tanggung jawab koperasi. ${ }^{13}$

12 Pasal 20 ayat (2) Keputusan Menteri Negara Koperasi dan Usaha Kecil dan Menengah Nomor 91/ Kep/M.KUKM/IX/2004 tentang Petunjuk Pelaksanaan Kegiatan Usaha Koperasi Jasa Keuangan Syariah

13 Burhanuddin S., Koperasi Syariah dan Pengaturannya di Indonesia, hlm. 57 
Untuk mendapatkan pengesahan badan hukum, para pendiri mengajukan permintaan tertulis disertai akta pendirian koperasi. Sedangkan yang dimaksud akta pendirian koperasi adalah surat keterangan tentang pendirian koperasi yang berisi pernyataan dari para kuasa pendiri yang ditunjuk dalam suatu rapat pembentukan koperasi untuk menandatangani anggaran dasar pada saat pembentukan koperasi. Untuk mendapatkan pengesahan akta pendirian koperasi, para pendiri perlu mengajukan permintaan pengesahan secara tertulis kepada lembaga yang terkait. Sebelum dimintakan pengesahan, penyusunan akta pendirian koperasi dapat dilakukan sendiri atau melalui notaris setelah berkonsultasi dengan pejabat yang berwenang. ${ }^{14}$ Pendirian koperasi yang berbadan hukum harus dilakukan melalui pengesahan akta otentik, yaitu akta yang dibuat oleh atau dihadapan notaris pembuat akta koperasi. Menurut Surat Keputusan Menteri Negara Koperasi dan Usaha Kecil dan Menengah Nomor: 98/KEP/M.KUKM /IX/2004, Notaris Pembuat Akta Koperasi adalah pejabat umum yang diangkat berdasarkan peraturan jabatan notaris yang diberi kewenangan antara lain untuk membuat akta pendirian, akta perubahan anggaran dasar dan akta-akta lainnya yang terkait dengan kegiatan koperasi. ${ }^{15}$

\section{Simpulan}

Prinsip-prinsip syariah dapat diimplementasikan dalam koperasi mulai dari saat pendirian hingga lingkup usahanya. Prinsip syariah yang harus diimplementasikan setiap kali akan mengadakan rapat anggota koperasi adalah prinsip syura. Kemudian untuk mengikat kerjasama modal diantara para anggota melalui simpanan pokok/ wajib yang jumlah nominalnya sama menggunakan syirkah mufawadhah, sedangkan simpanan sukarela yang jumlah nominalnya berbeda (syirkah inan). Para anggota yang diamanahi sebagai pengawas dan pengurus yang menjalankan usaha koperasi selain berhak mendapatkan SHU dari modal dan poin transaksi, juga berhak mendapatkan upah bulanan berdasarkan akad ijarah. Untuk pengembangan modal koperasi, pengelola koperasi dapat mengajukan pembiayaan baik kepada pihak internal anggota maupun kepada pihak eksternal mulai dari akad yang bersifat nirlaba (tabarru') seperti qardh hingga akad yang bersifat komersial (tijarah) seperti pembiayaan berbasis jual beli (murabahah, istishna), berbasis sewa menyewa (ijarah, $\underline{I M B T)}$ ), dan berbasis bagi hasil (musyarakah, mudharabab), dan lain-lain yang

14 Ketentun terkait berkas yang wajib dilampirkan untuk draft pendirian yang dibuat sendiri atau melalui notaris diatur Pasal 7 ayat (2) Peraturan Menteri Negara Koperasi dan Usaha Kecil dan Menengah Nomor 1/Per/M.KUKM/I/2006 tentang Petunjuk Pelaksanaan Pembentukan, Pengesahan Akta pendirian dan Perubahan Anggaran Dasar Koperasi.

15 Pasal 1 ayat (4) Surat Keputusan Menteri Negara Koperasi dan Usaha Kecil dan Menengah Republik Indonesia Nomor: 98/KEP/M.KUKM /IX/2004 tentang Notaris sebagai Pembuat Akta Koperasi 
bersifat modifikasi. Dengan mengimplentasikan prinsip-prinsip syariah dalam pembaharuan konsep badan hukum koperasi, diharapkan lebih membuka peluang bagi para praktisi perkoperasian untuk mengamalkan nilai-nilai illahiyah.

\section{Daftar Pustaka}

\section{Buku}

Al-Jazảiri, Jabir.Minhajul Muslim. edisi terjemahan. Malang: Universitas Islam Negeri Maulana Malik Ibrahim, 2014.

An-Nabhani, Taqiyuddin. An-Nizham al-Iqtishadifíal-Islam. Beirut: Darul Ummah, 1990.

Hibban, Ibn. Shahih ibn Hibban. Bairut: Muassasah al-Risalah, 1993.

Ghulam, Zainil. Implementasi Maqashid Syariah dalam Koperasi Syariah. Iqtishoduna: Jurnal Ekonomi Islam. Vol 5 No 1 (2016): April.

Marzuki, Peter Mahmud. Penelitian Hukum. Jakarta: Penerbit Prenanda Kencana, 2014.

S., Burhanuddin. Koperasi Syariah dan Pengaturannya di Indonesia. Malang: UIN Maliki Press, 2013.

\section{Peraturan PerUndang-Undangan}

Peraturan Menteri Negara Koperasi dan Usaha Kecil dan Menengah No: 1/Per/M. KUKM/I/2006 tentang Petunjuk Pelaksanaan Pembentukan, Pengesahan Akta pendirian dan Perubahan Anggaran Dasar Koperasi.

Peraturan Menteri Negara dan UKM Nomor 13 Tahun 2006 tentang Surat Utang Koperasi; Peraturan Menteri Negara Koperasi dan Usaha Kecil dan Menengah Nomor 13/ Per/M.KUKM/VII/ 2006 tentang Pedoman Teknis Program

Sekuritisasi Aset Koperasi dan KUKM.

Peraturan Pemerintah Nomor 33 Tahun 1998 tentang Modal Penyertaan Dalam Koperasi

Peraturan Menteri Negara Koperasi dan Usaha Kecil dan Menengah Nomor 1/Per/M. KUKM/I/2006 tentang Petunjuk Pelaksanaan Pembentukan, Pengesahan Akta pendirian dan Perubahan Anggaran Dasar Koperasi. 
Peraturan Mahkamah Agung Republik Indonesia No. 2 Tahun 2008 tentang Kompilasi Hukum Ekonomi Syariah

Surat Keputusan Menteri Negara Koperasi dan Usaha Kecil dan Menengah Republik Indonesia Nomor: 98/KEP/M.KUKM /IX/2004 tentang Notaris sebagai Pembuat Akta Koperasi

Surat Keputusan Menteri Negara Koperasi dan Usaha Kecil dan Menengah Nomor 91/Kep/M.KUKM/IX/2004 tentang Petunjuk Pelaksanaan Kegiatan Usaha Koperasi Jasa Keuangan Syariah 